多く含むことは, 結晶棈造の差異にも基くことはもちろんである が，ATS I 粒子が細かく，小なりとはい充吸着作用が一因をな していることは否めない。

付 記

参考のために ATS 法によりえられる酸化チタンの純度につい て記す。合成宝石用高純度匹塩化チタンおよび硫酸, 硫安の特級
13) Chem. Abst. 25, 1421 (1931); Erde 5, 554 (1930).
A. Neuhaus, Chem.

品を使用し，石英ガラス容器を用いて合成した ATS を焼成して えられた酸化チタンについて，中型石英分光分析装置にて定性的 に分光分析を行った結果, 痕跡の V を認めたのみで, $\mathrm{Cu}, \mathrm{Na}$, $\mathrm{Ca}, \mathrm{Zr}, \mathrm{Al}, \mathrm{W}, \mathrm{Fe}, \mathrm{Sb}, \mathrm{Mg}, \mathrm{Mn}, \mathrm{Si}$ の存在を認めなかっ た。硫安, 硫酸の 1 級品を使用し, 半工業的規模で収率よくATS を合成し，磁製ルッボで焼成した試料については $\mathrm{Na}, \mathrm{Ca}, \mathrm{Cu}$, $\mathrm{Zr}, \mathrm{V}, \mathrm{Al}$ の極く微量が検出された。

(昭和 32 年 11 月 14 日, 人工鉱物討論会で講演)

\title{
ベンジジンによるブドウ糖水溶液中の 5-(オキシメチル)-フルフラールの比色定量
}

\author{
（昭 和 32 年 12 月 26 日 受理)
}

\author{
吉 弘 芳 郎・中 村 亦夫*
}

\begin{abstract}
ブドウ糖水溶液中に微量に存在する 5-(オキシメチル)ーフルフラールは分光化学的検索で知ることができるが，その簡 易な定量法には適当なるのがない。著者らはこの簡易定量を目的として, フルフラールの呈色反応試薬を応用した比色定 量法を研究した。呈色試薬としてベンジジン一酢酸溶液を選び，反応条件について研究した結果，ブドウ糖水溶液中より 5-(オキシメチル)-フルフラールを水飽和 $n$-ブタノールで抽出し, 所定の反応を行わせることにより, ブドウ糖と5-(オ キシメチル)ーフルフラールの濃度比か 10000 対 1 にいたるまで，誤差 $5 \%$ 程度で簡易に测定することをえた。
\end{abstract}

\section{I. 緒 言}

ブドウ糖水溶液中に共存する微量の 5-(オキシメチル)-フルフ ラール（以下 HMF と略す）の検索 $1,2,3$ や定量には紫外スペクト ル分析法が用いられる。しかし，この方法は装置も高価であり， 一般的な工業分析法として適当なるのとは思われない。著者らは フルフラールの呈色試薬が HMF にる特有の吸収帯を有する色素 を生成することを応用し，その比色定量法を求めた。

フルフラールの呈色試薬には䣫酸ーアニリン4,5), キシリジン6), ベンジジン7) 等各種のるのがあり, それぞれその比色定量に応用 されている。これらの場合, $\mathrm{HMF}$ やメチルフルフラールの呈色 による影響が問題にならなかったのは, フルフラールの反応性が HMF 等にくらべてはるかに鋭敏であることや，生成色素の最大 波長が異なること, 更に分析操作上, HMF が分離されやすかっ たことに基因する。精製デンプンの酸糖化生成物の場 合のよ5 に,フルフラールやメチルフルフラールの存在がまず考えられな い場合には，これらの物質による呈色の影響がないので，上記の 方法は十分 HMF の定量に応用できよ5。

著者らは Kiermayer ${ }^{8)}$ 法でえた HMF を精製ブドウ糖に混合 して作成した標準試料を用い，呈色試薬としてベンジジンを用い た場合の比色定量の可否を検討した結果，多量のブドウ糖中に共

* 東京大学生産技術研究所：千葉市弥生町.

1) E. Lindemann, Die Stärke 7, 280 (1955).

2) M. L. Wolfrom, R. D. Schuetz, L.F. Cavalieri, J. Am. Chem. Soc. 70, 514 (1948).

3）水口, 鈴木, 元井, 堀家, 工化 60, 445 (1957).

4) R. A. Stillings, B. L. Browning, Ind. Eng. Chem. Anal. Ed. 12, 499 (1940).

5) R.E. Reeves, J. Munro, ibid. 12, 551 (1940).

6) Suminokra, Lab. Biol. Tottori Coll. 158 (1928).

7) R. A. McCance, Biochem. J. 20, 1110 (1926).

8) J. Kiermayer, Chem. Ztg. 19, 1003 (1895).
存する微量の HMF を簡易に測定することができたので報告する。

\section{II. 装置と試薬}

i）比色計：一日立慗 EPO-A 型光電比色計

ii) 試薬 : -

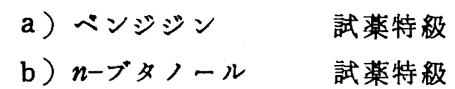

c）氷酢 酸 $\quad b p 118^{\circ} \mathrm{C}$ 蒸留精製

d）ブドウ糖旦本薬局方注射用

e ) $\mathrm{HMF} \quad$ Kiermayer 法にて調製 $\mathrm{mp} 31^{\circ} \mathrm{C}$

\section{III. 実験と考察}

フルフラールの呈色試薬は一般にその反応条件により呈色状態 が異なり，かつ生成した色が不安定という久点がある。フルフラ ールの比色定量という面からその反応条件の研究は行われ, 一応 の結果も出ているが，これが HMF の比色定量に適合するかどう かは不明である。著者らは，まずこの点についての研究を行っ た。

ベンジジンを呈色試薬として選んだ理由はこれがアニリンやキ シリジン等にくらべて実験操作が簡便であることによる。

\section{A. ヘンジジンの濃度について}

呈色試薬はベンジジンを酿酸に溶解したものを用いるが，その 場合のベンジジン濃度の検討をまず行った。HMF の標準 水溶液 $(50 \sim 200 \mathrm{\gamma} / \mathrm{cc})$ を作成し，これを各 $1 \mathrm{cc}$ ずつとり，n-ブタノー ル $4 \mathrm{cc}$ ずつ加え, 混和後混液のままべンジジンの水㼍酸溶液 $(0.2$ $\sim 2.0 \mathrm{~g} / 100 \mathrm{cc}$ ) を各 $5 \mathrm{cc}$ ずつ加光, $30^{\circ} \mathrm{C}$ の恒温槽中で 15 分 間反応後ただちに比色計で主波長 $460 \mathrm{~m} \mu$ のフィルターを用いて 吸光度を測定した結果を第 1 図に示す。

第 1 図の結果からみると, ベンジジンの濃度が増加するほど反 応は鋭敏になる。しかし，この反面生成した色が不安定になる傾 


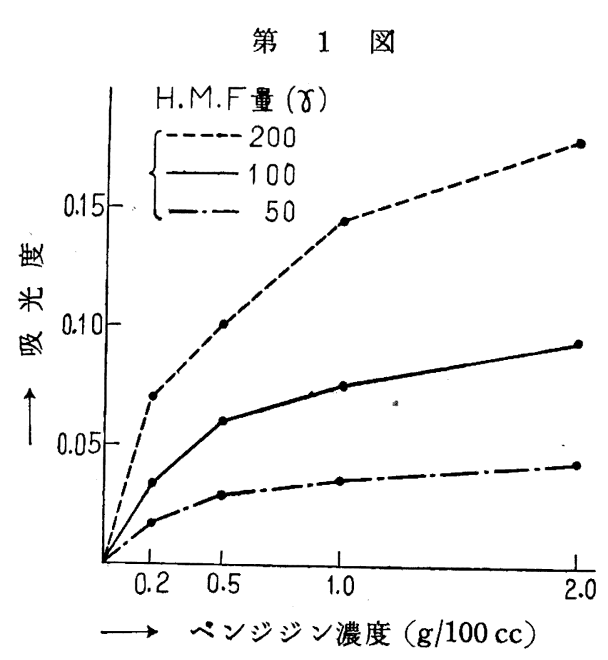

向がある。この 例として HMF 量 $50 \gamma / \mathrm{cc}$ の標 準溶液を用いて 同様に実験し， 生成した色素と 反応時間の関係 を第 2 図に示す。 また試験液に 含まれる HMF 量が多くなる と, 色が不安定 になる傾向があ る。第 3 図はこ

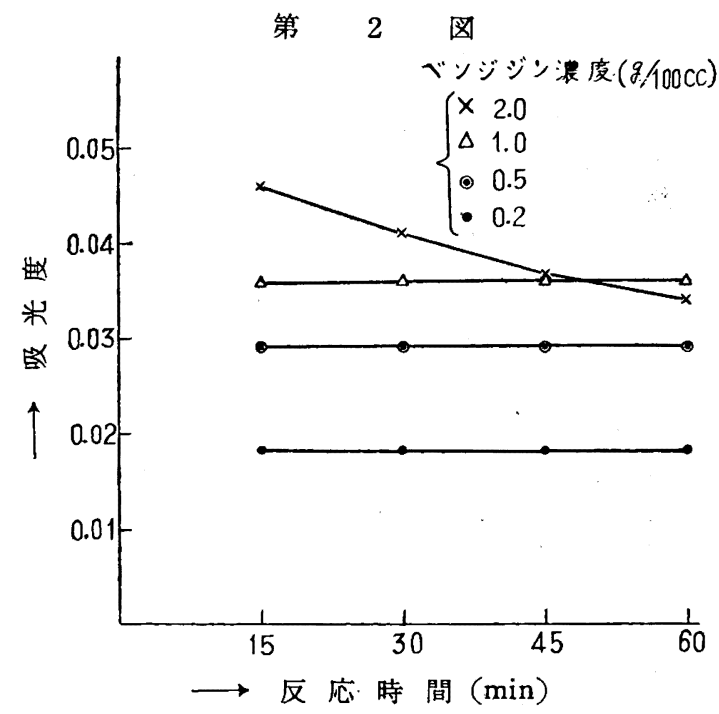

第 3 図

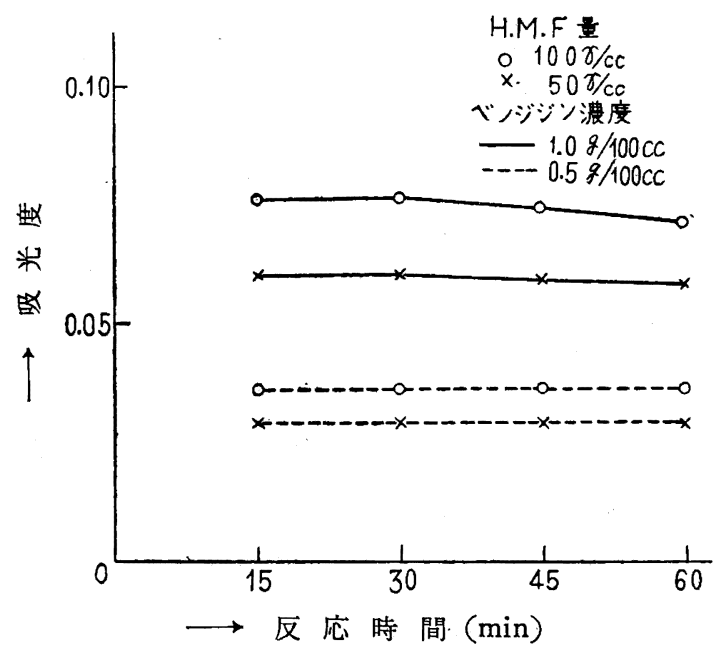

れを示したもので, これらの点からしてベンジジン濃度をただ高 めてもよい結果はえられない。われわれは吸光度と色の安定性の 二面より考虑し， ベンジジン濃度を $1.0 \mathrm{~g} / 100 \mathrm{cc}$ とし，反応時間 を 15 分ときめて実験を行った。

B. 酷酸淟度について

ベンジジンを水酢酸に溶解する代わりに, 酢酸水溶液に溶解し た場合の酢酸濃度が呈色反応にいかに影響するかを第 4 図に示 す。実験操作は HMF 量 $200 \gamma / \mathrm{cc}$ の標準溶液を用い, 呈色試薬

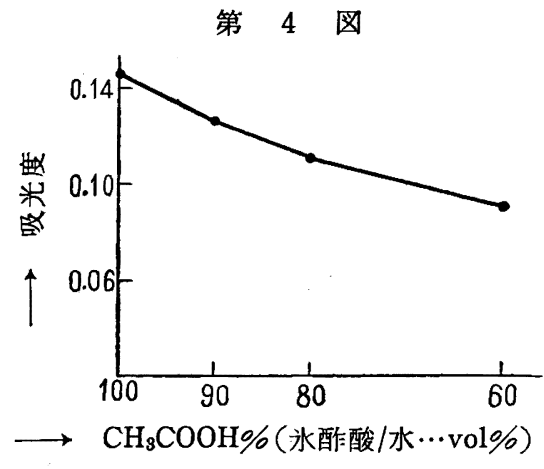

はベンジジン $1.0 \mathrm{~g}$ を 種々の濃度 $(60 \sim 100$ \%) の酢酸溶液 $100 \mathrm{cc}$ に溶解したものを用い た。HMF 標準溶液 1 ccをとり，4ccの $n$ ブタノールを加え混和 後, 混液のまま上記呈 色試薬を $5 \mathrm{cc}$ 加え 30 ${ }^{\circ} \mathrm{C}$ で 15 分間反応を行 わせ,ただちに比色計で吸光度を測定した。第 4 図の結果, 酢酸 は濃度が高いほど反応は鋭敏となる。したがって，呈色試薬はべ ンジジンを氷酢酸に溶解することにした。

C. nーブタノール澅度について

nーブタノールを用いる理由は, 後述するように HMFをその水 溶液より抽出することと, 呈色反応を鋭敏にすることである。 ブタノール濃度の呈色反応におよぼす影響をしらべるため, HMF 標準水溶液 $(200 \mathrm{r} / \mathrm{cc})$ をそれぞれ $1 \mathrm{cc}$ とり，nーブタノールを 1 4 cc 加え, 水を加えて全量を $5 \mathrm{cc}$ とし, ベンジジン $1.0 \mathrm{~g}$ を $100 \mathrm{cc}$ の氷酢酸溶解した呈色試薬を $5 \mathrm{cc}$ 加えて $30^{\circ} \mathrm{C} て ゙$ 15分間反応を行わせ，ただちに比色計で吸光度を測定した。その 結果を第 5 図に示す。 第 5 図の横軸は全反応

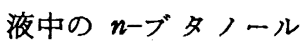
濃度 vol\% を表わす。 この結果, $n$-プタノ ール濃度は高いほど反 応が鋭敏になる。われ われは HMF 水溶液 $1 \mathrm{cc}$ に対し, $4 \mathrm{cc}$ の nープタノールを用いる ことにした。HMFを 第 5 図

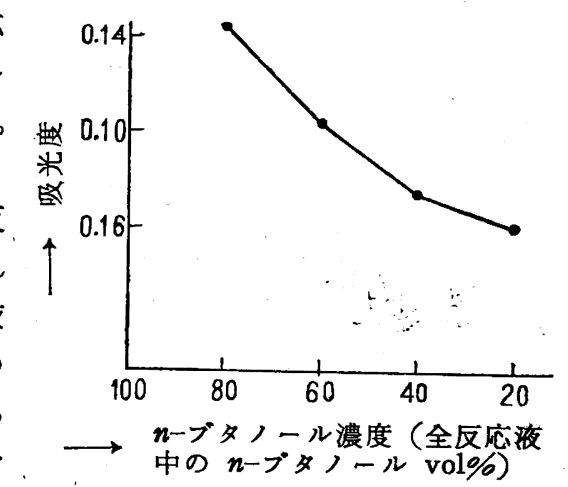
nーブタノールで抽出した場合には反応液中の $n$-ブタノール濃度 が常に $80 \%$ になるようにする。この場合 $n$ ーブタノールに溶解す る水量は無視しても実験には差支えがなかった。nーブタノール量 を 80\%にしたのは HMF の水溶液をそのまま測定することがて きるようにしたためである。

\section{D. 反応温度について}

色の安定性という点から, 反応温度について検討を行った。 $\mathrm{HMF}$ 標準水溶液 $(200 \mathrm{r} / \mathrm{cc})$ を $1 \mathrm{cc}$ とり，nーブタノールを $4 \mathrm{cc}$ 加光, 混和後混液のまま呈色試薬（ベンジジン $1.0 \mathrm{~g} 100 \mathrm{cc}$

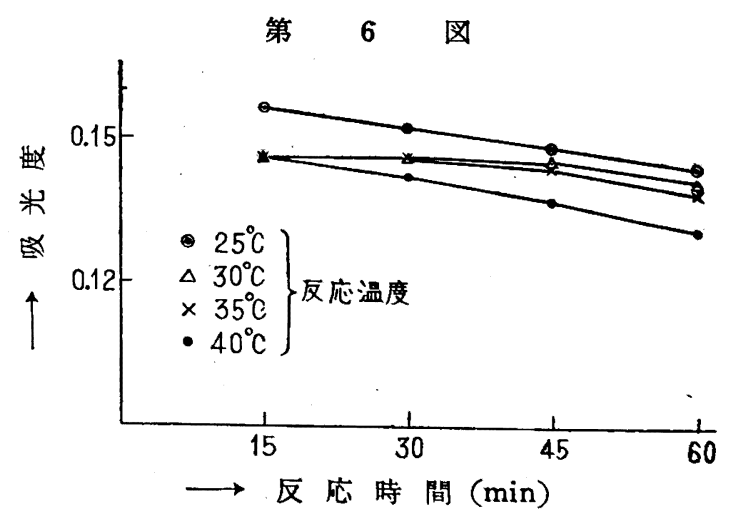


第 7 図

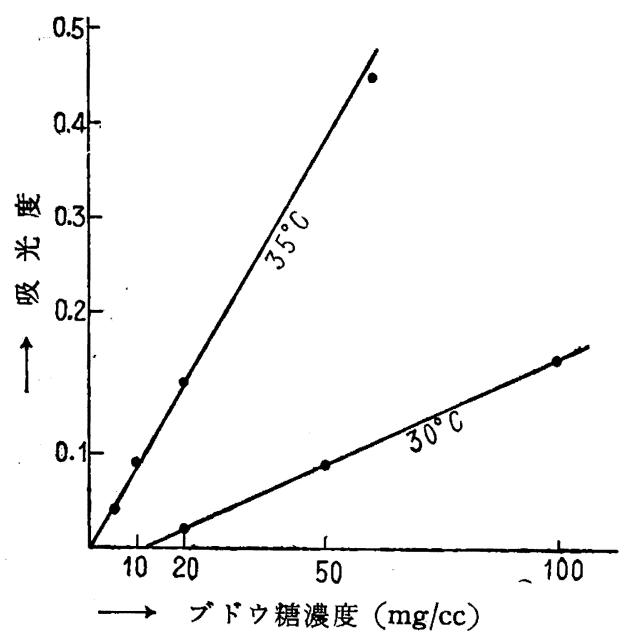

の兆醀酸に溶か

す) $5 \mathrm{cc}$ を加光， $25,30,35,40$ ${ }^{\circ} \mathrm{C}$, の各温度で 反応させ, 15 分 間隔に呈色状態 を比色計でしら ベた結果を第 6 困に示した。 この結果, 30 $\sim 35^{\circ} \mathrm{C}$ で応 を行うのが最良 と思われたが, $\mathrm{HMF}$ 水溶液の かわりにブドゥ

糖水溶液で同様実験した結果，第 7 図に示すよ 5 に $30^{\circ} \mathrm{C}$ で反応 させる方がブドウ糖の発色による影幚をさけやすくなることが判 明したので，反応温度を $30^{\circ} \mathrm{C}$ と決定した。

第 7 図からブドウ糖濃度の增加と着色量とは直線的関係がある ことがわかる。これより試検液中に存在するブドウ糖量がわかれ ば HMF を測定する時に現われるブドウ糖による影晦を補正する ことができる。

\section{E. フィルターの選定について}

ベンジジンー亦酢酸試薬を用いて HMF およびフルフラールを 呈色させたときの吸収曲線を第 8 図に示す。これらの標準水溶液 を各 $1 \mathrm{cc}$ とり， $4 \mathrm{cc}$ の $n$-ブタ ノールを加え混 和後, 混液のま ま $5 \mathrm{cc}$ の呈色 試薬 $(1.0 \mathrm{~g}$ の ペンジジンを $100 \mathrm{cc}$ の水酰酸 に溶解したも の)を加え $30^{\circ} \mathrm{C}$ で 15 分間反応 をさせ呈色させ た。別に蒸留水 を用いて同様に 第 8 図

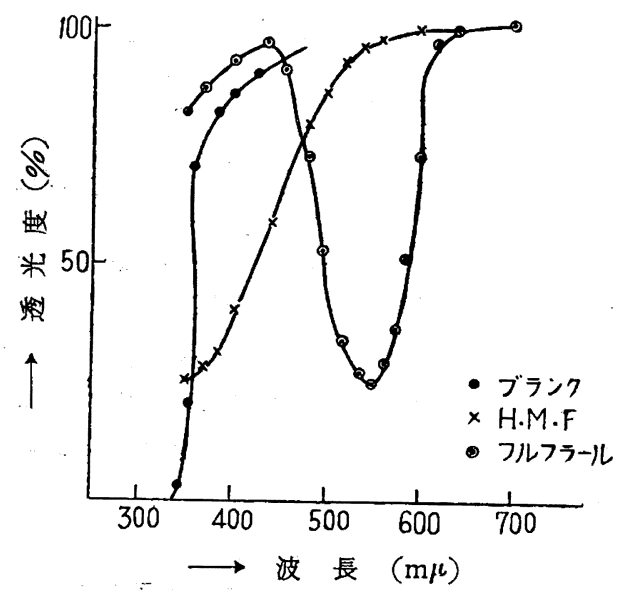

操作したものをブランクとした。光電比色計はベックマン DU 型 を用いた。フルフラール濃度は $18 \mathrm{\gamma} / \mathrm{cc}, \mathrm{HMF}$ 濃度は $100 \mathrm{\gamma} / \mathrm{cc}$ を使用した。フルフラールによる呈色色素の最大吸収波長は 550 $\mathrm{m} \mu$ にあり, HMF のそれはこれよりはるかに短波長にあるが， 最大吸収波長は測定でさなかった。これは試薬そのものが $400 \mathrm{~m} \mu$ 以下で透光度を急速に失っているためである。この原因は試薬中 のベンジジンによるものと考えられる。

日立製 EPO-A 型光電比色計付属のフィルターを用いて, HMF による呈色色素の透光度を求めると第 9 図のよ5になる。これよ クフィルター番号 B, 主波長 $460 \mathrm{~m} \mu$ のるのを使用することにし た。

\section{F. 梌量線の作成}

以上で大体 HMF 水溶液のベンジジンー氷酢酸試薬による比色
第 9 図

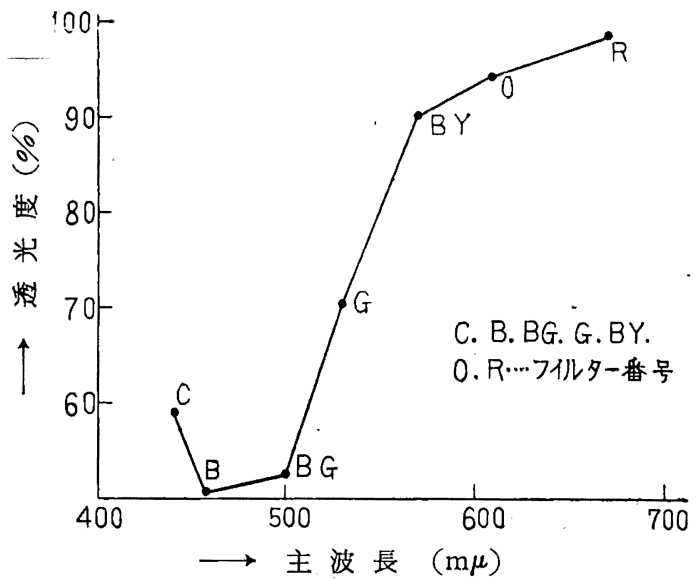

条件が定まった。これを要的すると次のようになる。

$\mathrm{HMF}$ 水溶液を $1 \mathrm{cc}$ とり,これに $n$ ーブタノール $4 \mathrm{cc}$ を加光混 和後, ベンジジンー氷酢酸試薬 $(1.0 \mathrm{~g} / 100 \mathrm{cc})$ を $5 \mathrm{cc}$ 加文, $30^{\circ} \mathrm{C}$ で 15 分間反応後，ただちに主波長 $460 \mathrm{~m} \mu$ のフィルターを用い て比色する。

$\mathrm{HMF}$ 標準水溶液 3 種以上を用いて括の括のについて数回実験 を行い，検量線を作成すると HMF 量 $200 \mathrm{\gamma} / \mathrm{cc}$ 以下では原点を 通る直線がえられる。200 $/ / \mathrm{cc}$ 以上ではベール，ランベルトの法 則にしたがわない傾向がある。

\section{G. ブドウ糖と HMF の水および水飽和ブタノールの分配係}

\section{数}

ブドウ糖水溶液中に存在する HMF を，水飽和ブタノールで抽 出し，できるだけブドウ糖の影響を除く方法を考え，そのためま ずブドウ糖と HMF のこれら 2 㬝への分配係数を測定した。

方法：一 既知濃度のブドウ糖溶液一定容量に等容量の水飽和

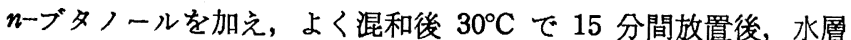
とブタノール凮の容積を測定し，水層中の糖濃度の減少量をブタ

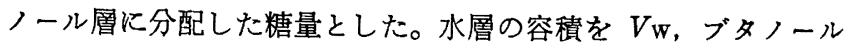
周を $V_{\mathrm{B}}$ ，水層の糖量を $M \mathrm{w}$, ブタノール層のそれを $M_{\mathrm{B}}$ とす ると分配係数は

$$
k_{1}=\frac{M_{\mathrm{B}} / V_{\mathrm{B}}}{M_{\mathrm{W}} / V_{\mathrm{W}}}=\frac{M_{\mathrm{B}}}{M_{\mathrm{W}}} \times \frac{V_{\mathrm{W}}}{V_{\mathrm{B}}}
$$

$30^{\circ} \mathrm{C}$ に拈ける $V_{\mathrm{W}} / V_{\mathrm{B}}$ を第 1 表に示す。

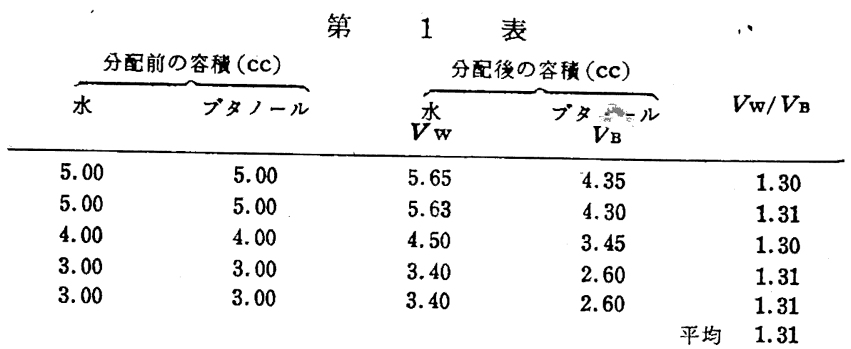

$30^{\circ} \mathrm{C}$ における $M_{\mathrm{B}} / M_{\mathrm{W}}$ を第 2 表に示す。

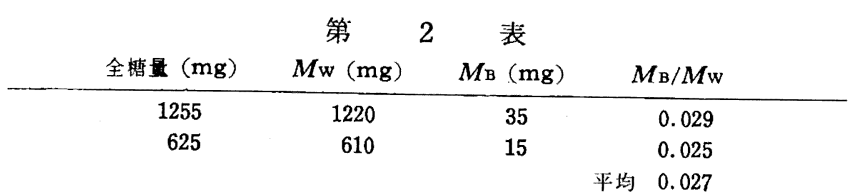

これらの値を（1）式に入れると

$$
k_{1}=0.027 \times 1.31=0.035
$$

糖量の測定はレーン氏法9)による。

9) J. H. Lane, L.Eynon, J. Soc. Chem. Ind. 42, 377 (1923). 
同様にして HMF の分配係数を求めた。ブタノール層の $\mathrm{HMF}$ 量を $m_{\mathrm{B}}$, 水層の $\mathrm{HMF}$ 量を $m_{\mathrm{W}}$ とすると $k_{1}$ に打けると同様 に HMF 分配係数を $k_{2}$ とすると

$$
k_{2}=\frac{m_{\mathrm{B}} / V_{\mathrm{B}}}{m_{\mathrm{W}} / V_{\mathrm{W}}}=\frac{m_{\mathrm{B}}}{m_{\mathrm{W}}} \times \frac{V_{\mathrm{W}}}{V_{\mathrm{B}}}
$$

$30^{\circ} \mathrm{C}$ に护ける $m_{\mathrm{B}} / m_{\mathrm{W}}$ を第 3 表に示す。ただし $\mathrm{HMF}$ 量の定 量は前記ベンジジンー皮酭酸法による。この場合は水層, ブタノ ール層の両方の HMF 量を測定できる。

\begin{tabular}{|c|c|c|c|c|c|}
\hline$m_{\mathbf{w}}(\gamma)$ & $m_{\mathbf{B}}(\gamma)$ & $m_{\mathrm{w}} / m_{\mathbf{B}}$ & $m_{\mathbf{w}}+m_{\mathbf{B}}$ & $\begin{array}{l}\text { HMF 理 } \\
\text { 論量 } \\
(\lambda)\end{array}$ & $(\%)$ \\
\hline 496 & 526 & 1.06 & 1022 & 1010 & +1.19 \\
\hline 400 & 428 & 1.07 & 828 & 808 & +2.50 \\
\hline 306 & 322 & 1.07 & 628 & 606 & +3.33 \\
\hline \multicolumn{2}{|c|}{$m_{\mathrm{W}} / m_{\mathbf{B}}$ : 平均 } & 1.07 & & & \\
\hline
\end{tabular}

これを（2）式に入れると

$$
k_{2}=1.07 \times 1.13=1.40
$$

$k_{1} ， k_{2}$ の值を比較すると，ブドウ糖水溶液より $\mathrm{HMF}$ がよく 抽出されることがわかる。しかも $k_{2}$ の値はフルフラールの塩酸 溶夜よりキシレンを用いてフルフラールを抽出する場合の分配係 数よりはるかに大である。

また

$$
\frac{m_{\mathrm{B}}}{m_{\mathrm{W}}}=1.07
$$

より

$$
\begin{gathered}
m_{\mathrm{W}}=\frac{m_{\mathrm{B}}}{1.07} \\
\text { 全 } \mathrm{HMF}=m_{\mathrm{B}}+m_{\mathrm{W}}=m_{\mathrm{B}}(1+1 / 1.07) \\
\text { 全 } \mathrm{HMF}=m_{\mathrm{B}} \times 1.93
\end{gathered}
$$

（3）式より，ブタノール層中の HMF 量を求めれば全 $\mathrm{HMF}$ が算出される。

\section{H. フドウ糖水溶液中に存在する微量 HMF の本法による定 量}

局方ブドウ糖に HMF を混合し，作成した標準試料を用い，前 記の定量法の実施可能性について検討を行った結果を第 4 表に示 す。方法は標準試料水溶液を $5 \mathrm{cc}$ とり，これに水飽和 $n$-ブタ， ール $5 \mathrm{cc}$ を加えてブタノール層に抽出された HMF を前記方法 で定量したものである。nーブタノール層には HMF のほかにブド ウ糖もわずかに分配してくるので，定量に用いた $n$ オブタノール

\begin{tabular}{|c|c|c|c|c|c|c|}
\hline $\begin{array}{l}\text { ブドウ標対 } \\
\text { HMF }\end{array}$ & $\begin{array}{l}\text { HMF } \\
\text { 理論是 } \\
\text { ( })\end{array}$ & 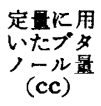 & 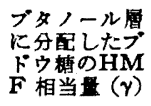 & $\begin{array}{c}n-7 ゙ タ ゙ '-~ \\
\text { ル啳 HMF } \\
(\gamma)\end{array}$ & $\begin{array}{l}\text { 金筷值 } \\
(\gamma)\end{array}$ & $\begin{array}{c}\text { 浼 差 } \\
(\%)\end{array}$ \\
\hline $2000: 1$ & 435 & 1.00 & 0 & 218 & 421 & -3.22 \\
\hline $2000: 1$ & 435 & 2.00 & 0 & 222 & 428 & -1.60 \\
\hline $5000: 1$ & 202 & 1.00 & 0 & 107 & 206 & +1.82 \\
\hline $5000: 1$ & 202 & 2.00 & 0 & 110 & 212 & +4.95 \\
\hline $10000: 1$ & 101 & 1.00 & 0 & 52.2 & 101 & 0 \\
\hline $10000: 1$ & 101 & 2.00 & 0 & 57.0 & 107 & +5.95 \\
\hline
\end{tabular}
の中に含まれるブドウ糖が多いとさは，これによる発色を考虑し
なければならない。分配したブドウ糖がわかれば第 7 因より，そ れに相当する吸光度が求められ，その吸光度に相当する HMF 量 がわかる。これがブタノール層に分配したブドウ糖の HMF 相当 量である。

第 4 表からブドウ糖水溶液中に含をれた微量の HMF を本法に より比色定量できることが判明した。ブドウ糖以外の糖としてマ ルトースについて考察を行ったが， マルトースの $n$ ーブタノール への分配はブドウ糖よりはるかに少なく，比色定量には問題にな らない。それ以上に分子量の大きなるのは同様に考えてよいと思 われる。本法は試料液が着色している場合は, 応用出来ぬ欠点が あるが, 脱色精製液中の HMF は簡単な操作で容易に測定できる。

以上の実験から，ブドウ糖液中の HMF の分析法を要約すれば 下記のようになる。

$\mathrm{HMF}$ 含有ブドウ糖液一定量に等容量の水飽和ブタノールを加 光, $30^{\circ} \mathrm{C}$ で 15 分間抽出し, 抽出ブタノール液を1〜3 cc 正確に とり，nーブタノールを加えて $4 \mathrm{cc}$ とし, 水 $1 \mathrm{cc}$ を加え, ベンジ ジンー氷眽酸試薬 $(1.0 \mathrm{~g} / 100 \mathrm{cc})$ を $5 \mathrm{cc}$ 加え, $30^{\circ} \mathrm{C}$ で 15 分間 反応後, 光電比色計で吸光度を求め, あらかじめ作成した検量線 よりブタノールに抽出された HMF 量を求め, これに係数を乗じ て全 $\mathrm{HMF}$ 量を求める。

な技市肘のレブリン酸（東京化成製）を用いて本試薬の反応を しらべた結果，呈色反応を認めなかったので，レブリン酸が漉在 しても測定に差支えない。

実験に使用したブドウ糖に含まれる HMF 量を求めるため, ブ ドウ糖水溶液 $(100 \mathrm{mg} / \mathrm{cc})$ を使用し，前述のベンジジン法によ る比色定量を行ったが，呈色しなかった。それ故，ここではブド ウ糖に含有されている HMF 量は無視した。

本研究は昭和 32 年, 化学関係学協会連合秋季研究発表大会講 演) 